\title{
Physical Condition for the Coronary Artery Disease Patients
}

\author{
Saghiv $\mathbf{M}^{1 *}$, Ben-Sira $\mathbf{D}^{2}$ and Sagiv $\mathbf{M}^{2}$ \\ ${ }^{1}$ Exercise Physiology Department, University of Mary, USA \\ ${ }^{2}$ Life Sciences Department, Wingate College, Israel
}

Submission: February 20, 2017; Published: April 03, 2017

*Corresponding author: Moran S Saghiv, Physiology Department Casey Center, Room 141B, University of Mary 7500, University Drive Bismarck, ND 58504, USA, Tel: 702-908-2390; Fax: 701-255-7687; Email: mssaghiv@umary.edu

Keywords: Aerobic exercise; Cardiac output; Maximal oxygen uptake

\section{Coronary Artery Disease Considerations}

A systematic review estimated that inactivity is responsible for $6 \%$ of the burden of disease from coronary heart disease worldwide [1]. CAD influence on work capacity and physical performance has been widely investigated. Myocardial functional changes include declines in maximum heart rate, stroke volume, left ventricular contractility and an increase in peripheral vascular resistance. Oxygen demand and supply for the Myocardium are normally balanced. Oxygen demand above quiescent needs of the Myocardium is determined by number of factors:

a) Heart rate-the greater the frequency of contractions, the greater the oxygen demand.

b) Myocardial wall tension is a function of both left ventricular systolic pressure and the ventricular radius [2].

c) The contractility of the heart-relates to the vigor and force of contraction influenced by an increase in circulating Catecholamine. Changes in structure and function of the cardiovascular system in CAD patients result in maximal oxygen uptake decline [3], which is the best single indicator of physical working capacity. Oxygen supply is the most important determinant of maximum oxygen uptake in health and disease [4], the low maximal oxygen uptake in the CAD patient may be the result of a decrease in oxygen supply (cardiac output) capacity, due to the CAD process, which has a genetic component. This coupled with the reduced ability of the working muscles to extract oxygen (arterio-venous oxygen difference) due to reduced muscle mass and function at maximal effort [5], ends up in significant reduced maximal oxygen uptake [6].
Mitochondrial density was found to be lower in skeletal muscle of CAD patients, oxidative capacity declines in some skeletal muscles which could further diminish capacity for endurance work [7]. CAD patients are not generally anemic and the red blood cell content is usually well maintained [8]. However, other studies $[9,10]$ do not support a causal role for muscular atrophy in the decline of maximal oxygen uptake. It seems that the related changes in maximal oxygen uptake are dependent on a number of factors including the onset of disease and level of physical activity. The highest rates of decline in maximal oxygen uptake are in those individuals that have reduced their levels of physical activity as they age. Cardiovascular system, morphological and physiological changes have been identified in the CAD patients.

Important factor that influence physical performance of the cardiac patient is aging associated with a shift in mechanism by which cardiac output is maintained during sub maximal exercise. In spite of having lower early diastolic filling rate during sub maximal exercise, end diastolic volume (the amount of blood filled in the ventricle at the end of diastole) is maintained and even increased as a function of age. As a result, CAD patients appear to have a greater reliance on the FrankStarling mechanism for the maintenance of cardiac output during sub maximal exercise [11].

\section{Aerobic Exercise Benefits for CAD Patients}

Following hospitalization, the patients are offered to attend a classical rehabilitation program with moderate exercise intensity. Aerobic exercise training is a major, and the most important, component of cardiac rehabilitation. 
The beneficial effects of cardiac rehabilitation are widely accepted for coronary artery diseases: reduction of $25 \%$ of the cardiovascular mortality at 3 years after myocardial infarction, improvement of the exercise tolerance and quality of life [12]. Moreover, patients who have left ventricular dysfunction post myocardial infarction, (ejection fraction $<45 \%$ ) improve their exercise tolerance $(+23 \%$ in peak V02) after training without significant deleterious ventricular remodeling $[13,14]$. Aerobic exercise reduces the risk of cardiovascular events in patients with prior CAD and thus, may also decrease the risk of mortality $[15,16]$.

Besides providing psychological benefits it exerts a positive effect on the risk profile for CAD patients with observed increases in circulating HDL and reductions in systolic and diastolic blood pressure. Exercise has also been considered to be useful for people at high risk for developing diabetes. Studies have shown that exercise has a preventive effect in people with a strong family history of CAD and diabetes when compared to high-risk people who were inactive $[17,18]$. The benefits of exercise can be gleaned from several short bouts of activity throughout the day [19]. The type of exercise can be subtle in nature, such as walking outdoors, on a treadmill, or through a mall. Simply increasing energy expenditure through an increase in daily living activities, such as climbing stairs or doing house or yard work, can help to increase energy output. After a patient establishes these routines and experiences the rewards of exercise, such as weight loss, psychological wellbeing, or an improvement in plasma glucose, lipids, or blood pressure, a more positive attitude toward exercise may result with even a further increase in activity. Recommendations to increase physical activity should be prefaced with an examination of current health status. If the patient has longstanding cardiac failure, it is practical to evaluate for left ventricular function complications that would be affected by exercise. The presence of previously diagnosed, and particularly undiagnosed, CHD is a critical factor in determining the intensity of any prescribed exercise program. Aerobic exercise reduces the risk of cardiovascular events in patients with prior CAD and thus, may decrease the risk of mortality [15]. Aerobic exercise decreases incidence and severity of cardiac events during exercise among an unselected group of patients with stable CAD [16,17]. In addition, exercise training improves endothelium-dependent vasodilatation both in epicardial coronary vessels and in resistance vessels in patients with CAD [18].

Aerobic exercise reduces the risk of cardiovascular events in patients with prior CAD and thus, may decrease the risk of mortality [15]. Aerobic exercise decreases incidence and severity of cardiac events during exercise among an unselected group of patients with stable CAD $[19,20]$. In addition, exercise training improves endothelium-dependent vasodilatation both in epicardial coronary vessels and in resistance vessels in patients with CAD [22].

Aerobic exercise decreases incidence and severity of cardiac events during exercise among an unselected group of patients with stable CAD [19,21]. In addition, exercise training improves endothelium-dependent vasodilatation both in epicardial coronary vessels and in resistance vessels in patients with CAD [22].

Table 1: Endurance training-induced changes in cardiovascular and hemodynamic variables in CAD patients.

\begin{tabular}{|c|c|c|c|}
\hline Variables & Rest & Sub-Max Exe & Max Exe \\
\hline $\begin{array}{c}\text { Oxygen uptake } \\
\text { pystolic blood } \\
\text { pressure }\end{array}$ & Unchanged & Unchanged & Increases \\
\hline $\begin{array}{c}\text { Diastolic blood } \\
\text { pressure }\end{array}$ & Decreases & Decreases & Decreases \\
\hline Stroke volume & Decreases & Increases & Decreases \\
\hline Heart rate & Decreases & Decreases & Unchanged \\
\hline Cardiac output & Unchanged & Unchanged & Increases \\
\hline Contractility & Unchanged & Unchanged & $\begin{array}{c}\text { Unchanged/ } \\
\text { Increases }\end{array}$ \\
\hline $\begin{array}{c}\text { Total } \\
\text { peripheral } \\
\text { resistance }\end{array}$ & Unchanged & Unchanged & Decreases \\
\hline $\begin{array}{c}\text { Arteriovenous } \\
\text { 02 difference }\end{array}$ & Unchanged & Unchanged & Increases \\
\hline
\end{tabular}

Table 1 summarizes some of the changes in cardiovascular and hemodynamic variables associated with training in CHD patients. Endurance exercise training in the CHD patients, decreased resting and sub maximal exercise heart rate, systolic and diastolic blood pressure while stroke volume increased. Marked changes are notable in the elderly subjects during maximal effort in which stroke volume, cardiac output, contractility, and oxygen uptake are increased, while total peripheral resistance, systolic and diastolic blood pressure decreased, thus lowering after-load which in turn facilitate left ventricular systolic and diastolic function.

When previously sedentary cardiac patients are re-tested at the same absolute sub-maximal work rate after adapting to endurance exercise, their endurance is found to be markedly increased. However, metabolic factors do not appear to determine the magnitude of VO2 max. The changes in muscle oxidative potential may play a major role in the patients capacity to perform sub-maximal work.

\section{Conclusion}

These data indicate that the coronary artery disease patients skeletal muscle, cardiovascular system and pulmonary function retain a high degree of trainability, with much of the improvement occurring peripherally, just as in younger individuals. 


\section{References}

1. Lee IM, Shiroma EJ, Lobelo F, Puska P, Blair SN, et al. (2012) Effect of Physical Inactivity on Major Non-Communicable Diseases Worldwide: An Analysis of Burden of Disease and Life Expectancy. Lancet 380(9838): 219-229.

2. Mann DL (2015) Braundwald's Heart Disease A textbook of Cardiovascular Medicine. (10th edn), Saunders, An imprint of Elsevier Inc, Netherlands, 2: 2128.

3. Belardinelli R, Lacalaprice F, Tiano L, Muçai A, Perna GP (2014) Cardiopulmonary exercise testing is more accurate than ECG-stress testing in diagnosing myocardial ischemia in subjects with chest pain. Int J Cardiol 174(2): 337-342.

4. Zakynthinos E, Pappa N (2009) Inflammatory biomarkers in coronary artery disease. J Cardiol 53(3): 317-333

5. Basset DR, Howley ET (2000) Limiting factors for maximum oxygen uptake and determinants of endurance performance. Med Sci Sports Exerc 32(1): 70-84.

6. Amani AR, Somchit MN, Konting MMB, Kok LY (2010) Relationship between Body Fat Percent and Maximal Oxygen Uptake among Young Adults. J Am Sci 6(4): 1-4.

7. Zoll J, Steiner R, Meyer K, Vogt M, Hoppeler H, et al. (2006) Gene expression in skeletal muscle of coronary artery disease patients after concentric and eccentric endurance training. Eur J Appl Physiol 96(4): 413-422.

8. Bogdanis GC (2012) Effects of physical activity and inactivity on muscle fatigue. Front Physiol 3: 142.

9. Ehsani AA, Ogana T, Miller TR, Spina RJ, Jilka SM (1991) Exercise training improves left ventricular systolic function in older men. Circulation 83(1): 96-103.

10. Marzolini S, Oh PI, Brooks D (2012) Effect of combined aerobic and resistance training versus aerobic training alone in individuals with coronary artery disease: a meta-analysis. Eur J Prev Cardiol 19(1): 81-94.

11. Sagiv M (2012) Exercise Cardiopulmonary Function in Cardiac Patients. Springer, London, pp. 171-194.

12. West RR, Jones DA, Henderson AH (2012) Rehabilitation after myocardial infarction trial (RAMIT): multi-centre randomised controlled trial of comprehensive cardiac rehabilitation in patients following acute myocardial infarction. Heart 98(8): 637-644.

13. Haykowsky M, Scott J, Esch B, Schopflocher D, Myers J, et al. (2011) A meta-analysis of the effects of exercise training on left ventricular remodeling following myocardial infarction: start early and go longer for greatest exercise benefits on remodeling. Trials 12: 92.

14. Doherty P, Salman A, Furze G, Dalal HM, Harrison A (2017) Does cardiac rehabilitation meet minimum standards: an observational study using UK national audit? Open Heart 4(1): e000519.

15. Swardfager W, Herrmann N, Cornish S, Mazereeuw G, Marzolini S, et al. (2012) Exercise intervention and inflammatory markers in coronary artery disease: a meta-analysis. Am Heart J 163: 666-676.

16. Pattyn N, Vanhees L, Cornelissen VA, Coeckelberghs E, De Maeyer C, et al. (2016) The long-term effects of a randomized trial comparing aerobic interval versus continuous training in coronary artery disease patients: 1-year data from the SAINTEX-CAD study. Eur J Prev Cardiol 23(11): 1154-1164.

17. Eriksson KF, Lindgarde F (1991) Prevention of type 2 diabetes mellitus by diet and physical exercise. Diabetologia 34(12): 891-898.

18. Manson JE, Nathan DM, Krolewski AS, Stampfer MJ, Willett WC, et al. (1992) A prospective study of exercise and incidence of diabetes among US male physicians. JAMA 268(1): 63-67.

19. Jakicic JM, Wing RR, Butler BA, Robertson RJ (1995) Prescribing exercise in multiple short bouts versus one continuous bout: effects on adherence, cardiorespiratory fitness, and weight loss in overweight women. Int J Obes Relat Metab Disord 19(12): 893-901.

20. Kodama S, Tanaka S, Saito K, Shu M, Sone Y, et al. (2007) Effect of aerobic exercise training on serum levels of high-density lipoprotein cholesterol: a meta-analysis. Arch Intern Med 167: 999-1008.

21. Bikdeli B, Ranasinghe I, Chen R, Gupta A, Lampropulos JF, et al. (2013) Most important outcomes research papers on treatment of stable coronary artery disease. Circ Cardiovasc Qual Outcomes 6(3): e17-e25.

22. Hambrecht R, Wolf A, Gielen S, Linke A, Hofer J, et al. (2000) Effect of Exercise on Coronary Endothelial Function in Patients with Coronary Artery Disease. N Engl J Med 342(7): 454-460.

This work is licensed under Creative

Commons Attribution 4.0 License

DOI: $10.19080 /$ JOCCT.2017.04.555633

\section{Your next submission with Juniper Publishers} will reach you the below assets

- Quality Editorial service

- Swift Peer Review

- Reprints availability

- E-prints Service

- Manuscript Podcast for convenient understanding

- Global attainment for your research

- Manuscript accessibility in different formats

( Pdf, E-pub, Full Text, Audio)

- Unceasing customer service

Track the below URL for one-step submission https://juniperpublishers.com/online-submission.php 